\title{
Giant Rugae in Helicobacter pylori-Infected Stomachs
}

\author{
Sun-Young Lee \\ Department of Internal Medicine, Konkuk University School of Medicine, Seoul, Korea
}

See "Endoscopic Characteristics of Rugal Hyperplasia and Related Acid Condition in Helicobacter pylori-Infected Stomach" by Byung Chul Kim, Mi Ae Song, Sung Ho Kwon, on page 73-84.

Giant gastric rugae are often found during upper gastrointestinal endoscopic examinations. Most of these hyperplastic rugae are induced by the Helicobacter pylori infection in East Asia, which increases the risk of gastric cancer. ${ }^{1}$ Nonetheless, data on the serum pepsinogen (PG) assay findings of rugal hyperplastic gastritis (RHG) are scarce. To resolve this issue, Kim et al. compared data between $H$. pylori-infected patients with and without RHG. ${ }^{2}$ They found that the serum PG I/II ratio was lower in patients with RHG than in $H$. pylori-infected patients without RHG. Such differences were significant only in patients with closed-type chronic atrophic gastritis (CAG) and not in those with open-type CAG.

Notable findings of this study were the use of the serum PG assay and the strict diagnostic criteria for endoscopic diagnosis. As summarized in their figures, Kim et al. followed detailed, endoscopic criteria to diminish interpersonal variability. ${ }^{2}$ By measuring the width of the gastric rugae with biopsy forceps after air inflation, they found a link between the low PG I/II ratio and the hypertrophic gastric rugae with a width $\geq 5 \mathrm{~mm}$ in patients with closed-type CAG. The lack of statistical significance among patients with open-type CAG might be due to the rarity of this disease and the persistently high PG II

Received: November 23, 2020 Revised: December 3, 2020

Accepted: December 4, 2020

Correspondence: Sun-Young Lee

Department of Internal Medicine, Konkuk University School of Medicine, 120-1 Neungdong-ro, Gwangjin-gu, Seoul 05030, Korea

Tel: +82-2-2030-7747, Fax: +82-2-2030-7748, E-mail: sunyoung@kuh.ac.kr ORCID: https://orcid.org/0000-0003-4146-6686

(c) This is an Open Access article distributed under the terms of the Creative Commons Attribution Non-Commercial License (http://creativecommons.org/ licenses/by-nc/3.0) which permits unrestricted non-commercial use, distribution, and reproduction in any medium, provided the original work is properly cited. levels found in $H$. pylori-induced corpus gastritis. ${ }^{3}$

Irrespective of the presence of the gastric rugae, the serum PG I and PG II levels increase with an active H. pylori infection and decrease with the progression to gastric corpus atrophy. ${ }^{4}$ Furthermore, when there is an active $H$. pylori infection, PG II levels correlate more with the gastric secretory ability than with PG I levels and PG I/II ratios. ${ }^{5}$ A high PG II level is a risk factor for diffuse-type gastric cancer, ${ }^{6}$ whereas low PG I/ II ratios and PG I levels are risk factors for intestinal-type gastric cancer. ${ }^{7}$ Giant rugae may progress to Bormann-type IV, a diffuse-type gastric cancer ${ }^{8}$; hence, high PG II levels are more reliable than low PG I/II ratios and PG I levels in patients with RHG.

Kim et al. analyzed $H$. pylori-infected patients with positive rapid urease test in their study. ${ }^{2}$ The gastric secretory ability significantly increased in $H$. pylori-infected patients with RHG, as demonstrated by their high serum PG I, PG II, and gastrin levels. Nevertheless, they concluded that most patients with RHG were in a hypoacidic condition because a hypoacidic stomach was diagnosed when the PG I/II ratio was $\leq 2.7$. It is important to exercise caution when interpreting these findings. Gastric acidity cannot be estimated solely from the PG I/II ratio in $H$. pylori-infected stomachs because PG levels increase during an active $H$. pylori infection. As demonstrated in Figure 3 by Kim et al., high PG II levels were consistently found with giant rugae regardless of the degree of $\mathrm{CAG}^{2}$ Moreover, most patients with RHG with a low PG I/II ratio ( $\leq 2.7$ ) showed high PG II levels. These patients were different from those with truly hypoacidic stomachs who showed low PG I/II ratios because of the low PG I levels. In other words, most patients with RHG included in their study did not have hypoacidic stomach, but they showed low PG I/II ratios owing 
to their high PG II levels.

Giant rugae findings that suggest the presence of cancerous lesions include poor distention on air inflation and persistently high serum PG II levels; they may indicate scirrhous or Borrmann type IV gastric cancer (Fig. 1). ${ }^{10}$ Other etiologies for giant rugae include gastric large B cell lymphoma, Menetrier disease, secondary inflammatory changes due to severe extragastric inflammation, parietal cell hyperplasia, and the polyposis syndrome (i.e., the Cronkhite-Canada syndrome, the juvenile polyposis syndrome, gastric hyperplastic polyposis, and familial adenomatous polyposis with fundic gland polyps). Regardless of the etiological differences (Table 1), gastric malignancies are often missed in the giant rugae because of the false-negative biopsy findings. Hence, it should be fol- lowed up with gastroscopy and serum PG assays, especially in $H$. pylori-infected patients after eradication of the infection. If giant rugae with poor distention and high PG II levels are persistent even after eradication of $H$. pylori, abdominal computed tomography and/or endoscopic ultrasonography should be performed to exclude gastric cancer lying beneath the rugae.

In summary, giant rugae show an increased gastric secretory ability in the presence of the $H$. pylori infection. Nonetheless, PG I/II ratios are low because PG II levels are higher than PG I levels. Therefore, in $H$. pylori-infected stomachs with high PG II levels, a low PG I/II ratio may not indicate hypochlorhydria. To detect gastric cancer in these patients, the persistence of giant rugae with poor distention and high serum PG II levels should be checked after $H$. pylori eradication.
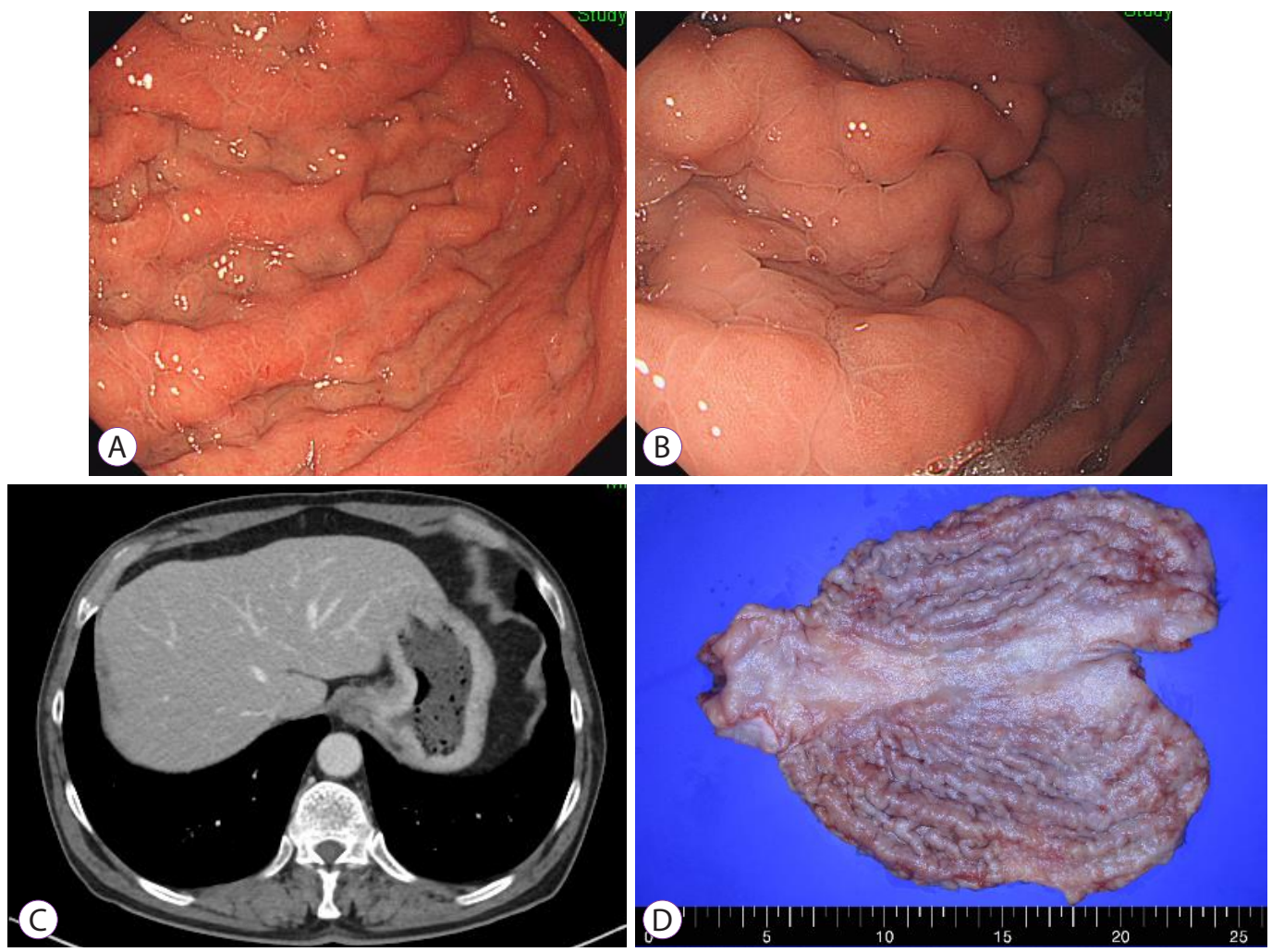

Fig. 1. Endoscopy and serum assay findings of the giant rugae in a 62-year-old man with an Helicobacter pylori infection. (A) Initial endoscopy of the gastric body: the mucosal surfaces of the gastric rugae showed diffuse redness and poor distention upon air inflation. Biopsies of the gastric rugae revealed an active $H$. pylori infection without malignant cells. The serum pepsinogen (PG) I $(91.6 \mathrm{ng} / \mathrm{mL})$ and PG II (15.5 ng/mL) levels were elevated, and the PG I / II ratio was 5.9 on the day of endoscopy. The serum anti-H. pylori lgG assay revealed seropositivity $(61.4 \mathrm{AU} / \mathrm{mL})$ using the Chorus $H$. pylori lgG assay (DIESSE, Siena, Italy), which has a sensitivity of $100 \%$ and a specificity of $75.4 \%$ in Korean. ${ }^{10}$ (B) Follow-up endoscopy after successful $H$. pylori eradication was confirmed by the negative urea breath test: poor distention was still noticed owing to the hard and thick rugae. Compared with the findings before the eradication, a progression to tortuosity was found in the giant rugae with the regression of diffuse redness. There were no malignant cells or $H$. pylori in the biopsied specimens. Nevertheless, the serum PG I (100.2 $\mathrm{ng} / \mathrm{mL}$ ) and PG II (16.8 ng/mL) levels were higher than those before the eradication. The PG I / II ratio was 6.0, and the serum anti-H. pylori lgG titer was 46.0 AU/mL. (C) Computed tomography of the abdomen: imaging was performed because of the persistent giant rugae and increased serum PG II levels after $H$. pylori eradication. A diffusely enhanced wall thickening of the entire stomach, suggesting Borrmann type IV gastric cancer, was found on a coronal section. (D) Gross image of the resected stomach: after total gastrectomy, a $19.0 \times 18.0 \times 1.0 \mathrm{~cm}$, diffuse-type, poorly cohesive carcinoma was diagnosed. Cancer cells were invading the visceral peritoneum (pT4a). Metastases were found in 17 of the 30 regional lymph nodes (pN3b). Resection margins were free of carcinoma. 
Table 1. Endoscopic Findings of Giant Gastric Rugae according to Its Etiology

\begin{tabular}{|c|c|c|c|c|c|}
\hline Etiology & Location & Primary lesion & Consistency & $\begin{array}{l}\text { Surface of gas- } \\
\text { tric mucosa }\end{array}$ & Coexisting diseases \\
\hline $\begin{array}{l}\text { Borrmann type IV gastric } \\
\text { cancer (linitis plastica) }\end{array}$ & $\begin{array}{l}\text { Corpus-dominant }> \\
\text { antrum-dominant }> \\
\text { junctional type }\end{array}$ & $\begin{array}{l}\text { Submucosa and/or } \\
\text { proper muscle }\end{array}$ & $\begin{array}{l}\text { Hard (poor air } \\
\text { inflation) }\end{array}$ & $\begin{array}{l}\text { Diffuse } \\
\text { redness and/ } \\
\text { or irregular } \\
\text { erosions/ul- } \\
\text { cerations }\end{array}$ & Helicobacter pylori infection \\
\hline Large B cell lymphoma & $\begin{array}{c}\text { All (multifocal, localized } \\
>\text { diffuse type) }\end{array}$ & $\begin{array}{l}\text { Mucosa and/or } \\
\text { submucosa }\end{array}$ & $\begin{array}{l}\text { Soft (preserved } \\
\text { distention) }\end{array}$ & $\begin{array}{l}\text { Diffuse } \\
\text { redness and/ } \\
\text { or irregular } \\
\text { erosions/ul- } \\
\text { cerations }\end{array}$ & Helicobacter pylori infection \\
\hline $\begin{array}{l}\text { Menetrier disease (hyper- } \\
\text { trophic protein-losing } \\
\text { gastropathy) }\end{array}$ & Corpus only & $\begin{array}{l}\text { Mucosa (lamina } \\
\text { propria })^{\mathrm{a})}\end{array}$ & $\begin{array}{l}\text { Soft (preserved } \\
\text { distention) }\end{array}$ & $\begin{array}{l}\text { Whitish exu- } \\
\text { date }\end{array}$ & $\begin{array}{l}\text { Anemia, edema due to hypoal- } \\
\text { buminemia, hypergastrinemia, } \\
\text { low acid secretion owing to } \\
\text { parietal cell loss, etc. }\end{array}$ \\
\hline $\begin{array}{l}\text { Cronkhite-Canada syn- } \\
\text { drome }\end{array}$ & Corpus $>$ antrum & Mucosa & $\begin{array}{l}\text { Soft (preserved } \\
\text { distention) }\end{array}$ & $\begin{array}{l}\text { Innumerable } \\
\text { hamartomas }\end{array}$ & $\begin{array}{l}\text { Colon tumors, alopecia, nail } \\
\text { atrophy, loss of taste, diarrhea } \\
\text { due to protein-losing enterop- } \\
\text { athy, etc. }\end{array}$ \\
\hline $\begin{array}{l}\text { Secondary inflammatory } \\
\text { change }\end{array}$ & All & $\begin{array}{l}\text { Outside the gastric } \\
\text { wall }\end{array}$ & $\begin{array}{l}\text { Soft (preserved } \\
\text { distention) }\end{array}$ & $\begin{array}{l}\text { Edematous } \\
\text { change }\end{array}$ & $\begin{array}{l}\text { Severe inflammation in the } \\
\text { abdomen (i.e., acute pancreati- } \\
\text { tis) }\end{array}$ \\
\hline
\end{tabular}

${ }^{a}$ In Menetrier disease, foveolar hyperplasia, glandular dilation, eosinophil and/or plasma cell infiltration, and smooth muscle hyperplasia are often found in the lamina propria.

\section{Conflicts of Interest}

The author has no potential conflicts of interest.

Funding

This work was supported by the Korean National Research Foundation 2016R1D1A1B02008937.

\section{ORCID}

Sun-Young Lee:

https://orcid.org/0000-0003-4146-6686

\section{REFERENCES}

1. Lee SY. [Helicobacter pylori infection and the Kyoto classification of gastritis]. Korean J Helicobacter Up Gastrointest Res 2019;19:81-87.

2. Kim BC, Song MA, Kwon SH. Endoscopic characteristics of rugal hyperplasia and related acid condition in Helicobacter pylori-infected stomach. Clin Endosc 2021;54:73-84.

3. Massarrat S, Haj-Sheykholeslami A, Mohamadkhani A, et al. Pepsinogen II can be a potential surrogate marker of morphological changes in corpus before and after H. pylori eradication. Biomed Res Int
2014;2014:481607.

4. Kim JH, Lee SY, Lee SP, et al. The histologic detection of Helicobacter pylori in seropositive subjects is affected by pathology and secretory ability of the stomach. Helicobacter 2018;23:e12480.

5. Tu H, Sun L, Dong X, et al. Serum anti-Helicobacter pylori immunoglobulin $\mathrm{G}$ titer correlates with grade of histological gastritis, mucosal bacterial density, and levels of serum biomarkers. Scand J Gastroenterol 2014;49:259-266.

6. Baek SM, Kim N, Kwon YJ, et al. Role of serum pepsinogen II and Helicobacter pylori status in the detection of diffuse-type early gastric cancer in young individuals in South Korea. Gut Liver 2020;14:439-449.

7. Cha JH, Jang JS. Clinical correlation between serum pepsinogen level and gastric atrophy in gastric neoplasm. Korean J Intern Med 2020;35:550-558.

8. Ichinose M, Watanabe M, Kato J. Re: Development of diffuse carcinoma in the gastric corpus in patients with rugal hyperplastic gastritis. Int J Cancer 2013;133:2259.

9. Iijima K, Koike T, Abe Y, Shimosegawa T. Cutoff serum pepsinogen values for predicting gastric acid secretion status. Tohoku J Exp Med 2014;232:293-300.

10. Lee SY, Moon HW, Hur M, Yun YM. Validation of western Helicobacter pylori IgG antibody assays in Korean adults. J Med Microbiol 2015;64(Pt 5):513-518. 